\title{
Anti-Muellerian Hormone Type-2 Receptor Extracellular Domain
}

National Cancer Institute

\section{Source}

National Cancer Institute. Anti-Muellerian Hormone Type-2 Receptor Extracellular

Domain. NCl Thesaurus. Code C147927.

Anti-Muellerian hormone type-2 receptor extracellular domain is encoded by the human AMHR2 gene. This protein may play a role in ovarian carcinogenesis. 